\title{
19.
}

\section{Mourão, C. (2015). A Toca do Lobo. Portugal: Laranja}

Azul

\section{Paulo Cunha}

Aparentemente, $A$ Toca do Lobo é um filme familiar. Não é familiar como outros filmes amadores caseiros que registam momentos importantes para os núcleos familiares (aniversários, festas, férias, etc...), mas é familiar porque $A$ Toca do Lobo é um filme sobre Tomaz Xavier de Azevedo Cardoso de Figueiredo (1902-1970) feito pela sua neta, a realizadora Catarina Mourão, e protagonizado por uma das suas filhas (Maria Rosa Figueiredo, mãe da realizadora) e por dois dos seus bisnetos (Francisca e Lourenço, filhos da realizadora). Indiretamente, também é protagonizado, na sua gritante ausência, pela tia da realizadora, Maria Antónia Figueiredo, que cortou relações com a irmã há mais de 30 anos.

Mas, contra as aparências, $A$ Toca do Lobo não é um filme familiar. Não é familiar porque, em rigor, o filme funciona sobretudo como uma metáfora de um drama maior, um drama nacional de um país que viveu grande parte do séc. XX sob ditadura e fala sobretudo sobre as dificuldades de lidar com essa herança, em enfrentar os fantasmas do passado. Aquilo que está no centro do filme é o fenómeno da não-inscrição, conforme proposto por José Gil em Portugal, Hoje. O Medo de Existir. "a não-inscrição do nosso passado salazarista teve efeitos de incorporação inconsciente do espaço traumático, não-inscrito, nas gerações que se seguiram" (Gil, 2005: 43). A não-inscrição supõe uma existência essencialmente passiva dos indivíduos, amarrados a uma realidade indefinida, mas sobretudo "suspende o desejo" e cria "simulacros de inscrições - para que tudo ficasse num meio-termo indefinido, e os portugueses se convencessem de que estavam a inscrever quando estavam precisamente a fugir à inscrição" (Gil, 2005: 4950). 
Não deixa de ser simbólico que sejam as segundas (a realizadora) e terceiras (os bisnetos) gerações, que nunca conheceram pessoalmente o avô/bisavô, a enfrentar e questionar esse incómodo passado. Ao contrário da geração anterior, as gerações de Catarina e dos seus filhos rejeitam o medo horizontal da hierarquia familiar e social (representada pela figura tutelar da tia Maria Antónia, a "guardiã" da Casa de Casares e da memória oficial acerca de Tomaz Figueiredo), desafiando uma cultura do medo instalada durante décadas.

Ao longo de um interessante e fascinante processo de pesquisa, acompanhamos a realizadora (que também narra o filme em off) através de todo o tipo de pistas: depoimentos, cartas, relatórios médicos e policiais, objetos (os saquinhos dos cachimbos ou a enigmática bolinha de prata), fotografias e outras imagens de arquivo. É sobretudo por isso que $A$ Toca do Lobo é essencialmente um docudrama, servido sob uma capa de documentário convencional, mas repleto de nuances melodramáticas soberbamente construídas pela realizadora. Mourão tem consciência do potencial dramático da história que quer contar: um dos melhores exemplos é o momento premonitório em que Tomaz Figueiredo se dirige a uma hipotética futura neta chamada Catarina. Os depoimentos são fundamentais para contextualizar a narrativa subjetiva, ambígua e parcelar de Catarina Mourão, que parece mais interessada em desenvolver um esquema melodramático, sempre a espreitar o psicodrama familiar, do que a descobrir a verdade objetiva, seja isso o que for. Por exemplo, a impossibilidade de visitar o interior da Casa de Casares ou a "página proibida" no processo da PIDE sobre o seu tio são oportunidades aproveitadas eximiamente para especular sobre o que poderia ser, tanto o filme como a vida da sua família.

Mas tudo isso é feito de forma metódica e consciente. Catarina Mourão produziu este filme enquanto parte prática de um curso de doutoramento concluído em 2016 e intitulado The Wolf's Lair: dreams and fragmented memories in a first-person essay film. Nesse trabalho, a realizadora pretende precisamente explorar o que define como "arquivo subjetivo", ou seja, a apropriação subjetiva dos arquivos familiares construídos essencialmente pela memória ("as verdadeiras mentiras da memória"): no caso, as imagens em $16 \mathrm{~mm}$ do programa Clube de Coleccionadores da RTP, o álbum de família da mãe da realizadora e o filme caseiro de $9,5 \mathrm{~mm}$. Neste contexto, Mourão conclui que "para a construção da nossa identidade, memória e história pessoais, não há respostas certas ou erradas", e é por isso que o seu objetivo é reler os documentos disponíveis, questionar a sua aparente verdade e redefinir a ideia de arquivo, explorando "fontes mais subjectivas e invisíveis, tais como as memórias, as memórias bloqueadas, sonhos e outras auto-manifestações inconscientes" (Mourão, 2016: 149). 
E nesse complexo processo, o dispositivo cinema ocupa um papel fundamental. Antes de mais, enquanto tecnologia que permite materializar a memória e os sonhos, mas também enquanto exercício privilegiado para repensar o género documental ou a nãoficção, e as suas aceções de verdade e realidade históricas, questionando as suas regras clássicas e explorando as suas potencialidades.

\section{Referências bibliográficas}

Gil, J. (2005). Portugal, Hoje. O Medo de Existir. Lisboa: Relógio d'Água.

Mourão, C. (2016). The Wolf's Lair: dreams and fragmented memories in a first-person essay film. Edinburgh: PhD thesis, Edinburgh College of Arts/The University of Edinburgh.

Paulo Cunha é doutor em Estudos Contemporâneos pela Universidade de Coimbra, com uma tese sobre políticas públicas e modos de produção no cinema português. Leciona nos cursos de Cinema da Universidade da Beira Interior. É investigador Integrado no LabCom.IFP da Universidade da Beira Interior. É coordenador editorial da Aniki: Revista Portuguesa da Imagem em Movimento. 